\title{
Regenerative Potential of Non-Vital Immature Permanent Maxillary Central Incisors using Platelet Rich Fibrin Scaffold- A Prospective Cohort Study.
}

Kritika Selvakumar ( $\nabla$ drkritikaselvakumar22@gmail.com )

SRM Dental College

\section{Sujatha V}

SRM Dental College

Srinivasan $\mathbf{N}$

Hamad Medical Corporation

Senthil Kumar Renganathan

SRM Dental College

Sekar Mahalaxmi

SRM Dental College

\section{Research Article}

Keywords: Apical diameter, Immature teeth, Platelet rich fibrin, Regeneration, Root length.

Posted Date: February 23rd, 2021

DOI: https://doi.org/10.21203/rs.3.rs-144905/v1

License: (c) (i) This work is licensed under a Creative Commons Attribution 4.0 International License. Read Full License 


\section{Abstract}

Regenerative endodontic procedures has gained momentum as a treatment modality of young immature permanent teeth. Literature reports reveal that platelet rich fibrin (PRF) stimulates growth factors and induces regeneration. This study was undertaken to assess the regenerative potential of non-vital immature permanent maxillary central incisors using PRF with a follow up for $2 y r s .19$ patients in the age group of 9-25yrs with immature, non-vital permanent maxillary central incisors $(n=23)$ with/without signs and/or symptoms of periapical pathosis and open apex were included in this study. In the first appointment, access opening, canal disinfection and triple antibiotic paste placement was done. In the subsequent visit, PRF was prepared and placed inside the canal. Access was sealed with Mineral trioxide aggregate plug and composite. The patient was reviewed upto $24 \mathrm{mths}$. The mean difference was statistically analysed using Friedman test followed by Dunn post hoc test and adjusted by Bonferroni correction $(p<0.05)$. As per AAE guidelines, the primary and secondary goals were achieved. A significant $(p<0.001)$ gradual increase in the root length, thickness of dentinal walls and decrease in apical diameter were observed. Within the limitations of this study, PRF placement was clinically and radiographically effective in inducing regeneration of non-vital immature permanent teeth.

\section{Introduction}

Pulp necrosis as a result of trauma or other insults interrupts the process of root maturation and apical closure in young permanent teeth ${ }^{1}$. A twelve year review of literature states that $25 \%$ school children and $33 \%$ adults experience trauma to their permanent dentition with the majority of these occurring before the age of 19 years $^{2}$. The treatment of young immature permanent teeth with pulp necrosis is therefore challenging to dental practitioners ${ }^{3}$. A paradigm shift towards regenerative endodontics (RE) facilitated continued root maturation and apical closure. RE is defined "as a biological procedure that predictably replaces damaged, diseased or missing structures including dentin and root structures as well as cells of the pulp-dentin complex (PDC), with viable tissues preferably of the same origin, that restore the normal physiologic functions of the PDC" 4 .

Tissue engineering and tissue regeneration form the backbone of RE; the former utilizes specific stem cells, three dimensional scaffolds and growth factors to regenerate PDC, the latter involves disinfection and revascularization of the PDC ${ }^{4,5}$.

A scaffold is a physicochemical three dimensional structure facilitating cellular organisation and vascularisation. Natural scaffolds such as platelet rich plasma (PRP) and platelet rich fibrin (PRF) are advantageous over synthetic polymers and collagen in terms of cost, inflammatory reactions, immune responses and cytotoxicity ${ }^{6}$. 
According to the current available data, revascularization through blood clot technique and scaffold implantation remains the techniques which have been clinically attempted. Although revascularization using blood clot was effective, the clot formed was unpredictable to serve as a scaffold. On the other hand, scaffold implantation with platelet concentrates delivers enhanced concoction of growth factors

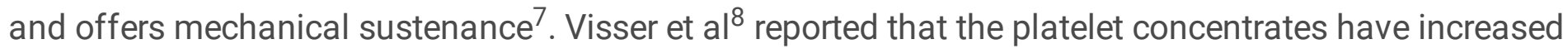
concentration of growth factors and increased cellular proliferation when compared to blood clot.

PRF is an autologous tri-molecular or equilateral fibrin branched junctional matrix which is expedient over PRP in terms of ease of preparation and use of anticoagulants ${ }^{9,10}$. According to Huang et $\mathrm{al}^{5}$, PRF can stimulate pulp cell proliferation, enhance osteoprotegrin protein expression and induce alkaline phosphatase activity.

According to a data analysis on clinical protocols in RE therapy, the overall percentage of studies in which intracanal bleeding or PRP/PRF was used is only $13 \%$ with insufficient evidence using a large sample size available in the literature ${ }^{11}$.

Hence the aim of this in vivo prospective cohort study was to evaluate the regenerative potential of scaffold implantation technique with PRF in non-vital immature permanent maxillary central incisors with a follow up period of 2 years. In accordance to the American Association of Endodontists (AAE) guidelines (8.5.2014), the primary and secondary goals were set as follows:

Primary : Elimination of the symptoms of pain / swelling (before scaffold implantation procedure) with evidence of bony healing and resolution of apical radiolucency (observed 6-12 months after treatment).

Secondary : Increase in root length and root dentin thickness (observed at 12-24 months after treatment) and decrease in apical diameter.

Tertiary : Positive pulp vitality response (which if achieved, could indicate a more organised vital pulp tissue).

\section{Methods}

\section{Patient Recruitment}

Nineteen patients (4 patients with 2 teeth each) in the age group of 9-25 years with immature, non-vital permanent maxillary central incisors $(n=23)$ with/without signs and/or symptoms of periapical pathosis (PAl index-upto scale 2 - small changes in bone structure) and open apex (apical diameter greater than $1.1 \mathrm{~mm}$ ) were included in this study. The study protocol was presented to the Institutional Review Board and approval was obtained based on the regulation of the Ethical Committee of the Faculty of Dentistry, SRM Institute of Science and Technology (SRMDC/IRB/2014/MDS/No.304) and registered in Clinical Trial Registry of India (CTRI/2017/10/010246) (30/10/2017). Patients were explained about the treatment protocol and informed consent was obtained from the patient and his/her parent (if the patient 
was less then 18 years of age). Detailed medical and dental histories, and clinical examination with pulp sensibility testing and radiographic examination of the involved teeth were carried out to confirm the diagnosis. Teeth with closed apex, caries lesions, periodontally compromised teeth, resorption, teeth with fracture/cracks, teeth other than maxillary central incisors were excluded. All procedures were carried out in accordance to the Ethical Committee guidelines of SRM Institute of Science and Technology and AAE guidelines for regenerative endodontics (8.5.2014).

\section{Treatment Procedure}

\section{Appointment 1}

Local anesthesia (LA) was administered using $2 \%$ lignocaine without vasoconstrictor by infiltration technique. Under rubber dam isolation and aseptic conditions, access cavity was prepared using a sterile No:1 Endo access and Endo 'Z' bur (Dentsply Maillefer, USA). After working length (WL) determination, minimal instrumentation was done and the canal was irrigated using $10 \mathrm{ml}$ of $1 \%$ sodium hypochlorite ( $\mathrm{NaOCl}$ ) (Chenchems Reagent, Chenchemicals, Chennai, India) for 2 minutes with side vented needles placed $1 \mathrm{~mm}$ short of WL. The canals were dried using paper points $2 \mathrm{~mm}$ short of the WL. Triple antibiotic paste (TAP) - containing ciprofloxacin, metronidazole and amoxicillin in the ratio of 1:1:1, mixed with $0.5 \mathrm{~mL}$ of propylene glycol was placed in the coronal third of the root canal. The pulp chamber was then temporarily restored with Cavit G (3M ESPE, Germany) and a radiograph was taken. The patient was recalled after 3 weeks.

\section{Appointment 2}

Preparation of PRF by Choukron's method

$10 \mathrm{~mL}$ of whole blood was withdrawn from the median cubital vein of the patient using $10 \mathrm{~mL}$ disposable syringe and needle. The blood was collected in a sterile glass test tube and centrifuged at $3300 \mathrm{rpm}$ for 12 minutes. The resultant membrane was then placed between 2 sterile gauze pieces and squeezed to form a strong fibrin network.

\section{Placement of PRF}

Under aseptic conditions and rubber dam isolation, the temporary restoration was removed and the TAP was flushed out copiously with saline. Canal irrigation was done using $10 \mathrm{~mL}$ of $1 \% \mathrm{NaOCl}$ and a final rinse with $5 \mathrm{~mL}$ of $17 \%$ EDTA (Chenchems Reagent, Chenchemicals, Chennai, India) solution. The canal was dried with paper points and the thin strands of PRF were cut and placed into the root canal space using Buchanan hand pluggers (Sybron Endo, Glendora, CA) $1 \mathrm{~mm}$ beyond the working length and coronally just below the CEJ. MTA (MTA Angelus, Angelus, Brazil) plug of $3 \mathrm{~mm}$ was packed coronally over the PRF scaffold. The canal orifice was sealed with Type II glass ionomer cement (GC, Tokyo, Japan) and the tooth was finally restored using composite resin (Te-Econom Plus, Ivoclar Vivadent, Mumbai, India) and a digital radiograph was taken. 


\section{Follow up analysis}

The routine follow up was carried out using clinical and radiographic assessments at $3,6,9,12,15,18$ month intervals and for a period of 24 months. The radiographs were digitally recorded and quantitative analysis was done using the SOPRO imaging software. As stated earlier, the primary and secondary objectives were measured in the follow up analysis.

\section{Statistical Analysis}

The quantitative measurements obtained from radiographs of different time periods were tabulated in an excel sheet and analysed statistically using SPSS software version 22. The data were assessed for normality and found to be non-normal in distribution. Hence non- parametric test, the Friedman test followed by Dunn post hoc test with Bonferroni correction was employed to detect the statistical significant difference in the regeneration (assessed by the various parameters - apical diameter, root length and thickness of dentin wall) over a period of 24 months. The $p$ value was set at $5 \%$.

\section{Results}

The primary objective was achieved in all the patients, wherein no patients reported with symptoms, clinical and radiographic signs of failure during any of the follow up periods. The mean and standard deviation of various parameters assessing the regeneration is mentioned in table 1. A significant increase in root length, thickness of dentinal wall in the apical third of the root dentin was observed from 12 months onwards when compared to the preop values $(p<0.001)$. However, the mesial and distal dentin thickness at the middle third showed a statistically significant increase only from 18 months and 24 months onwards $(p<0.05)$. A highly significant decrease in apical diameter was noticed from 12 months onwards $(p<0.001)$. 
Table 1: Mean (Standard deviation) of Difference between Pre- and Post-operative values of various parameters indicating the regeneration

\begin{tabular}{|c|c|c|c|c|c|c|c|c|}
\hline Parameters & Pre-Op & $\begin{array}{l}3 \\
\text { Months }\end{array}$ & $\begin{array}{l}6 \\
\text { Months }\end{array}$ & $\begin{array}{l}9 \\
\text { Months }\end{array}$ & $\begin{array}{l}12 \\
\text { Months }\end{array}$ & $\begin{array}{l}15 \\
\text { Months }\end{array}$ & $\begin{array}{l}18 \\
\text { Months }\end{array}$ & $\begin{array}{l}24 \\
\text { Months }\end{array}$ \\
\hline $\begin{array}{l}\text { Apical } \\
\text { Diameter } \\
(\mathrm{mm})\end{array}$ & $0^{\mathrm{a}}$ & $0^{a}$ & $0^{\mathrm{a}}$ & $\begin{array}{l}0.300^{\mathrm{a}} \\
(0.47)\end{array}$ & $\begin{array}{l}0.83^{b} \\
(0.38)\end{array}$ & $\begin{array}{l}1.09^{\mathrm{b}} \\
(0.288)\end{array}$ & $\begin{array}{l}1.35^{\mathrm{b}} \\
(0.487)\end{array}$ & $\begin{array}{l}1.83^{\mathrm{b}} \\
(0.388)\end{array}$ \\
\hline $\begin{array}{l}\text { Root Length } \\
(\mathrm{mm})\end{array}$ & $0^{\mathrm{a}}$ & $0^{\mathrm{a}}$ & $0^{\mathrm{a}}$ & $\begin{array}{l}0.48^{\mathrm{a}} \\
(0.51)\end{array}$ & $\begin{array}{l}0.91^{\mathrm{b}} \\
(0.28)\end{array}$ & $\begin{array}{l}1.17^{b} \\
(0.388)\end{array}$ & $\begin{array}{l}1.57^{\mathrm{b}} \\
(0.507)\end{array}$ & $\begin{array}{l}1.91^{\mathrm{b}} \\
(0.417)\end{array}$ \\
\hline $\begin{array}{l}\text { Thickness of } \\
\text { Mesial } \\
\text { Dentinal } \\
\text { wall- Apical } \\
\text { third (mm) }\end{array}$ & $0^{\mathrm{a}}$ & $0^{\mathrm{a}}$ & $0^{\mathrm{a}}$ & $\begin{array}{l}0.04^{\mathrm{a}} \\
(0.20)\end{array}$ & $\begin{array}{l}0.70^{\mathrm{b}} \\
(0.47)\end{array}$ & $\begin{array}{l}0.96^{\mathrm{b}} \\
(0.209)\end{array}$ & $\begin{array}{l}1.00^{\mathrm{b}} \\
(0.000)\end{array}$ & $\begin{array}{l}1.04^{\mathrm{b}} \\
(0.209)\end{array}$ \\
\hline $\begin{array}{l}\text { Thickness of } \\
\text { Distal } \\
\text { Dentinal } \\
\text { wall - } \\
\text { Apical third } \\
(\mathrm{mm})\end{array}$ & $0^{a}$ & $0^{a}$ & $0^{\mathrm{a}}$ & $\begin{array}{l}0.43^{\mathrm{a}} \\
(0.50)\end{array}$ & $\begin{array}{l}0.87^{b} \\
(0.34)\end{array}$ & $\begin{array}{l}1.00^{\mathrm{b}} \\
(0.000)\end{array}$ & $\begin{array}{l}1.04^{\mathrm{b}} \\
(0.209)\end{array}$ & $\begin{array}{l}1.04^{\mathrm{b}} \\
(0.209)\end{array}$ \\
\hline $\begin{array}{l}\text { Thickness of } \\
\text { Mesial } \\
\text { Dentinal } \\
\text { wall- } \\
\text { Middle } \\
\text { third (mm) }\end{array}$ & $0^{\mathrm{a}}$ & $0^{\mathrm{a}}$ & $0^{\mathrm{a}}$ & $0^{\mathrm{a}}$ & $\begin{array}{l}0.13^{\mathrm{a}} \\
(0.34)\end{array}$ & $\begin{array}{l}0.30^{\mathrm{a}} \\
(0.470)\end{array}$ & $\begin{array}{l}0.48^{b} \\
(0.511)\end{array}$ & $\begin{array}{l}0.57^{b} \\
(0.507)\end{array}$ \\
\hline $\begin{array}{l}\text { Thickness of } \\
\text { Distal } \\
\text { Dentinal } \\
\text { wall- } \\
\text { Middle } \\
\text { third (mm) }\end{array}$ & $0^{\mathrm{a}}$ & $0^{\mathrm{a}}$ & $0^{\mathrm{a}}$ & $0^{\mathrm{a}}$ & $0^{\mathrm{a}}$ & $\begin{array}{l}0.26^{\mathrm{a}} \\
(0.449)\end{array}$ & $\begin{array}{l}0.30^{\mathrm{a}} \\
(0.470)\end{array}$ & $\begin{array}{l}0.52^{\mathrm{b}} \\
(0.511)\end{array}$ \\
\hline
\end{tabular}

Different alphabetical superscript for each time period indicates the statistical significant difference from the pre-op value $(p<0.05)$.

\section{Discussion}

The prerequisites essential for root maturation include the presence of wide open apex for tissue ingrowth, young aged individuals where high stem cell regeneration potential is present, cautious use of sodium hypochlorite as an irrigant for effective disinfection and the use of triple antibiotic paste as intra canal medicament ${ }^{3}$. Another major factor is the initiation and/or placement of a scaffold that creates a platform for regeneration to occur. An appropriate scaffolding must yield a correct spatial location of 
stem cells and regulate its differentiation, proliferation and metabolism by inducing growth factors ${ }^{9}$. The growth factors present in PRP and PRF such as platelet derived growth factor, transforming growth factor, insulin like growth factor etc stimulate mitogenic response leading to proliferation and differentiation of the Stem Cells of Apical Papilla (SCAP) into odontoblasts which are influenced by the cells of the Hertwig's epithelial root sheath (HERS) ${ }^{4}$. These odontoblasts deposit atubular dentin at the apical and lateral walls of the root canal leading to continued root maturation ${ }^{12}$.

Simonpieri et al ${ }^{13}$ stated that PRF acts as a biological connector between bone particles thereby maintaining and protecting grafted biomaterials, facilitates cell migration for neoangiogenesis, promotes healing by release of cytokines, up regulates the inflammatory process and acts as an anti-infectious agent. Ulusoy et al ${ }^{14}$ compared the use of a blood clot, PRP, PRF and platelet pellets as scaffolds for RE therapy and concluded that the platelet derivatives yielded a higher rate and prolonged exposure to the growth factors with less chances of obliteration of the canal space.

Studies have proven the effectiveness of revascularisation procedures in adolescent age group because of increase in the differentiating ability of the stem cells in terms of quantity, quality and mobilization capacity unlike in aged individuals. On the contrary, there is growing evidence that mesenchymal stem cells recruited in the RE procedure are either less prone to ageing or elude ageing indefinitely ${ }^{7}$. Therefore a wide range of patients between the age group of 9 to 25 years was chosen in the study. Avoiding mechanical debridement of canal walls and use of lower concentration of $\mathrm{NaOCl}$, further ensures the vitality of $\mathrm{SCAP}^{15}$. $\mathrm{NaOCl}$ at concentrations greater than $3 \%$ is found to be cytotoxic to periodontal ligament cells and SCAP cells ${ }^{16}$. Martin et al ${ }^{17}$ stated that $17 \%$ EDTA when used as the final irrigant partially reverses the detrimental effects of high concentrations of sodium hypochlorite solution and has a positive effect on the survival and differentiation of SCAP. The modified version of TAP suggested by Thomson et $\mathrm{al}^{18}{ }^{18}$, where minocycline was replaced with amoxicillin and used in combination with ciprofloxacin and metronidazole to prevent discoloration was employed in our study. An optimal coronal seal is essential to prevent the ingress of bacteria. Therefore a tight coronal seal was established with 3$4 \mathrm{~mm}$ thickness of MTA placed coronally over the PRF scaffold ${ }^{19}$.

The primary objective of RE was achieved at 6 months follow up period, in all the cases with complete resolution of symptoms and periapical radiolucencies, where existed. Literature reveals few studies on quantitative analysis in $\mathrm{RE}^{20-22}$. Hence our study also focussed on the quantitative radiographic assessment of the secondary objectives such as root length, apical diameter and thickness of dentinal walls. A significant overall mean decrease of $88.40 \%$ in apical diameter and an increase of $16.92 \%$ in root length were observed. Since the coronal thirds of all the teeth were fully developed, we analysed the changes in the dimensions of the middle and apical thirds of the mesial and distal dentinal walls. There was a significant increase in the thickness of both the walls in the middle and apical thirds. When compared with the preoperative values, significant difference in all the parameters was observed from the $12^{\text {th }}$ month onwards. 
Chen et $\mathrm{al}^{23}$ reported five types of responses in the regeneration of immature teeth : type I - increased thickening of the canal walls and continued root maturation, type II- no significant continuation of root development with blunt and closed root apex, type III- continued root development with open apical foramen, type IV- severe calcification (obliteration) of the canal space and type $\mathrm{V}$ - formation of a hard tissue barrier between the coronal MTA plug and the root apex. In our study at 2 years, Type III was observed in all the teeth except one, suggesting complete root maturation (Fig. 1,2). In only one case, a type $V$ response was noticed (Fig. 3). The probable reason could have been the MTA placement upto the middle third which induced the hard tissue barrier formation.

Based on the literature evidence put forth the following mechanisms for root maturogenesis can be considered:

- Few vital pulp cells remain at the apical canal end which has the ability to resist destruction even in the presence of inflammation and has the ability to proliferate and differentiate into odontoblasts .

- The periodontal ligament stem cells have the ability to proliferate and grow within the apical end of the canal lumen through the open apex in cases where there is destruction of HERS and SCAP.

- The PRF acts as a reservoir of growth factors which stimulates the differentiation, growth and maturation of fibroblasts, odontoblasts and cementoblasts from their undifferentiated precursors ${ }^{24}$.

Although controversies exists on the clinical vitality status of the teeth treated with RE, the pulp sensibility assessment - cold test carried out during the follow up period was found to be negative, probably due to the thick coronal seal of 3-4mm with MTA and composite resin diminishing the chances to know the exact vitality status.

According to Ritter et $\mathrm{al}^{25}$, in the study conducted on dog teeth, it was reported that the ingrowth of tissue is more likely to originate from periodontal ligament consisting of bone, cementum and dentin like material rather than pulp tissue. As there is limited literature evidence substantiating the type and nature of newly formed tissue, further studies have to be undertaken in this aspect.

Limitations: Grey MTA used in the study resulted in discolouration of all teeth.

\section{Conclusion}

Within the limitations of the present in vivo prospective cohort study, it can be concluded that the use of platelet rich fibrin as a scaffold has proven to be clinically and radiographically effective in terms of increase in root length, decrease in apical diameter and increase in dentin wall thickness in all subjects when tested over a 2 year follow up period. Thus regenerative endodontics using scaffold implantation technique (PRF) can be a viable alternative treatment option over other techniques for non-vital immature permanent teeth.

\section{Declarations}


Funding: This research did not receive any specific grant from any funding agency in the public, commercial, or not-for-profit sectors.

Conflict of interest: The authors declare that there is no conflict of interest.

\section{References}

1. Nagaveni, N.B., Pathak, S, Poornima, P. \& Joshi, J.S. Revascularization induced maturogenesis of non-vital immature permanent tooth using platelet-rich-fibrin: a case report. J Clin Pediatr Dent. 40(1), 26-30 (2016).

2. Glendor, U. Epidemiology of traumatic dental injuries-a 12 year review of the literature. Dent Traumatol. 24(6), 603-11 (2008).

3. Hargreaves, K.M., Giesler, T., Henry, M. \& Wang, Y. Regeneration potential of the young permanent tooth: what does the future hold?. Pediatr Dent. 30(3), 253-60 (2008).

4. Murray, P.E., Garcia-Godoy, F. \& Hargreaves, K.M. Regenerative endodontics: a review of current status and a call for action. $J$ Endod. 33(4), 377-90 (2007).

5. Huang, F.M., Yang, S.F., Zhao, J.H. \& Chang, Y.C. Platelet-rich fibrin increases proliferation and differentiation of human dental pulp cells. J Endod. 36(10),1628-32 (2010).

6. Mishra, N., Narang, I. \& Mittal, N. Platelet-rich fibrin-mediated revitalization of immature necrotic tooth. Contemp Clin Dent. 4(3), 412 (2013).

7. Jadhav, G.R., Shah, N. \& Logani, A. Platelet-rich plasma supplemented revascularization of an immature tooth associated with a periapical lesion in a 40-year-old man. Case Rep Dent. doi: 1155/2014/479584 (2014)

8. Visser, L.C., Arnoczky, S.P., Caballero, O. \& Egerbacher, M. Platelet-rich fibrin constructs elute higher concentrations of transforming growth factor- $\beta 1$ and increase tendon cell proliferation over time when compared to blood clots: a comparative in vitro analysis. Vet Surg.39(7), 811-7 (2010).

9. Dohan, D.M. et al. Platelet-rich fibrin (PRF): a second-generation platelet concentrate. Part I: technological concepts and evolution. Oral Surg Oral Med Oral Pathol Oral Radiol Endodontol.101(3),e37-44 (2006).

10. Lucarelli, E. et al. A recently developed bifacial platelet-rich fibrin matrix. Eur Cell Mater. 20(1),13-23 (2010).

11. Kontakiotis, E.G., Filippatos, C.G., Tzanetakis \& G.N., Agrafioti, A. Regenerative endodontic therapy: a data analysis of clinical protocols. J Endod. 41(2), 146-54 (2015).

12. Shivashankar, V.Y., Johns, D.A., Vidyanath, S. \& Sam, G. Combination of platelet rich fibrin, hydroxyapatite and PRF membrane in the management of large inflammatory periapical lesion. $J$ Conserv Dent. 16(3), 261 (2013).

13. Simonpieri, A., Del Corso, M., Sammartino, G. \& Ehrenfest, D.M. The relevance of Choukroun's plateletrich fibrin and metronidazole during complex maxillary rehabilitations using bone allograft. Part I: a 
new grafting protocol. Implant Dent. 18(2), 102-11(2009).

14. Ulusoy, A.T., Turedi, I., Cimen, M. \& Cehreli, Z.C. Evaluation of blood clot, platelet-rich plasma, plateletrich fibrin, and platelet pellet as scaffolds in regenerative endodontic treatment: a prospective randomized trial. J Endod. 45(5), 560-6 (2019).

15. Wigler, R., Kaufman, A.Y., Lin, S., Steinbock, N., Hazan-Molina, H. \& Torneck, C.D. Revascularization: a treatment for permanent teeth with necrotic pulp and incomplete root development. J Endod. 39(3), 319-26 (2013).

16. Chang, Y.C., Huang, F.M., Tai, K.W. \& Chou, M.Y. The effect of sodium hypochlorite and chlorhexidine on cultured human periodontal ligament cells. Oral Surg Oral Med Oral Pathol Oral Radiol Endodontol. 92(4), 446-50 (2001).

17. Martin, D.E. et al. Concentration-dependent effect of sodium hypochlorite on stem cells of apical papilla survival and differentiation. J Endod. 40(1), 51-5 (2014).

18. Thomson, A. \& Kahler, B. Regenerative endodontics-biologically-based treatment for immature permanent teeth: a case report and review of the literature. Aust Dent J. 55(4), 446-52 (2010).

19. Banchs, F. \& Trope, M. Revascularization of immature permanent teeth with apical periodontitis: new treatment protocol?. J Endod. 30(4), 196-200 (2004).

20. Tawfik, H., Abu-Seida, A.M., Hashem, A.A. \& Nagy, M.M. Regenerative potential following revascularization of immature permanent teeth with necrotic pulps. Int Endod J. 46(10), 910-22 (2013).

21. Bose, R., Nummikoski, P. \& Hargreaves, K. A retrospective evaluation of radiographic outcomes in immature teeth with necrotic root canal systems treated with regenerative endodontic procedures. $J$ Endod. 35(10), 1343-9 (2009).

22. Cehreli, Z.C., Isbitiren, B., Sara, S. \& Erbas, G. Regenerative endodontic treatment (revascularization) of immature necrotic molars medicated with calcium hydroxide: a case series. J Endod. 37(9), 132730 (2011).

23. Chen, M.H., Chen, K.L., Chen, C.A., Tayebaty, F., Rosenberg, P.A. \& Lin, L.M. Responses of immature permanent teeth with infected necrotic pulp tissue and apical periodontitis/abscess to revascularization procedures. Int Endod J. 45(3), 294-305 (2012).

24. Nagy, M.M., Tawfik, H.E., Hashem, A.A. \& Abu-Seida, A.M. Regenerative potential of immature permanent teeth with necrotic pulps after different regenerative protocols. J Endod. 40(2), 192-8 (2014).

25. Ritter, A.L., Ritter, A.V., Murrah, V., Sigurdsson, A. \& Trope, M. Pulp revascularization of replanted immature dog teeth after treatment with minocycline and doxycycline assessed by laser Doppler flowmetry, radiography, and histology. Dent Traumatol. 20(2), 75-84 (2004).

\section{Figures}



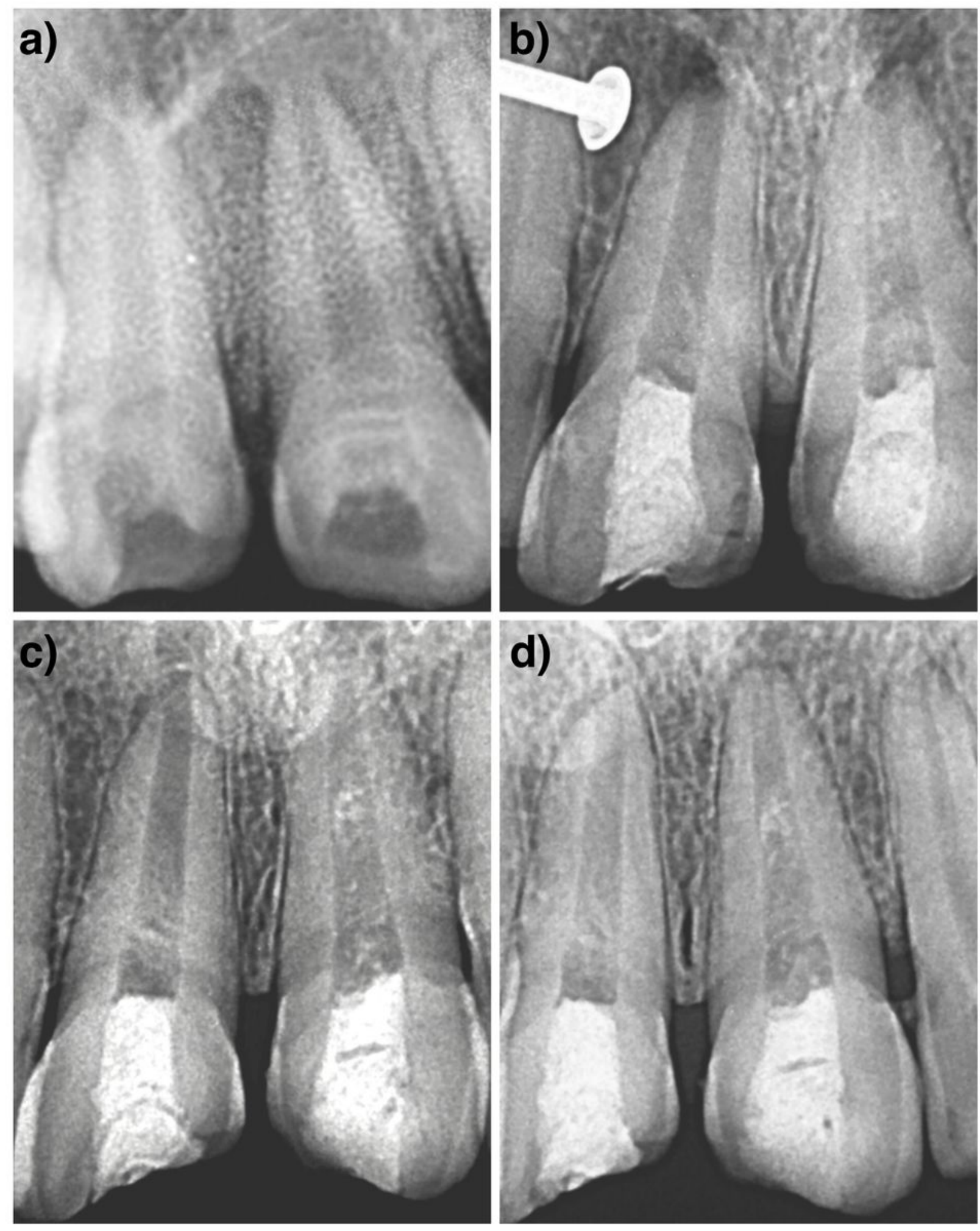

\section{Figure 1}

Case 1 : Tooth no. 11, 21- (A)Preoperative radiograph; (B-D)Radiographs at 6 months, 12 months and 24 months follow up period. 

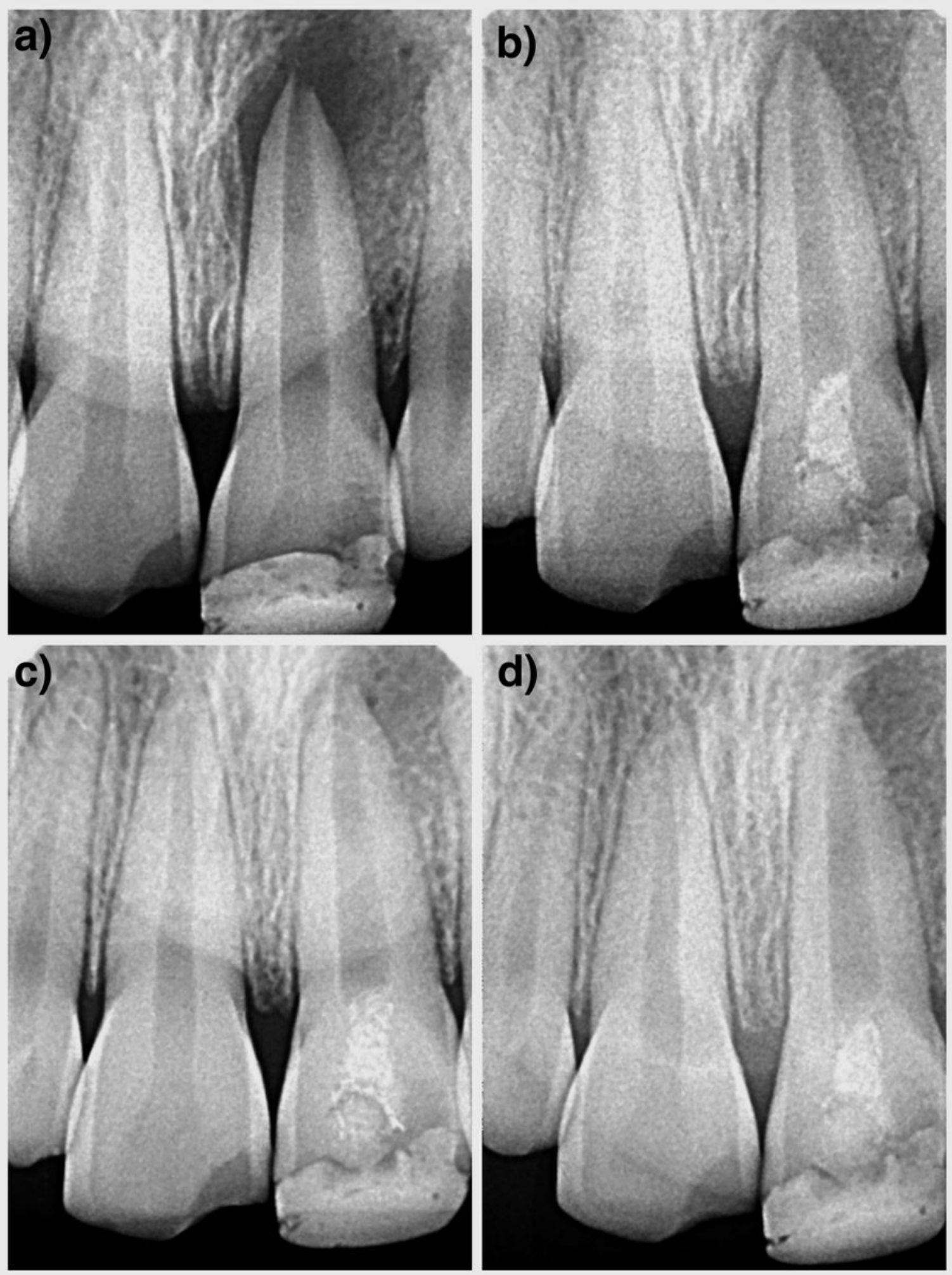

Figure 2

Case 2 : Tooth no. 21- (A)Preoperative radiograph; (B-D)Radiographs at 6 months, 12 months and 24 months follow up period. 

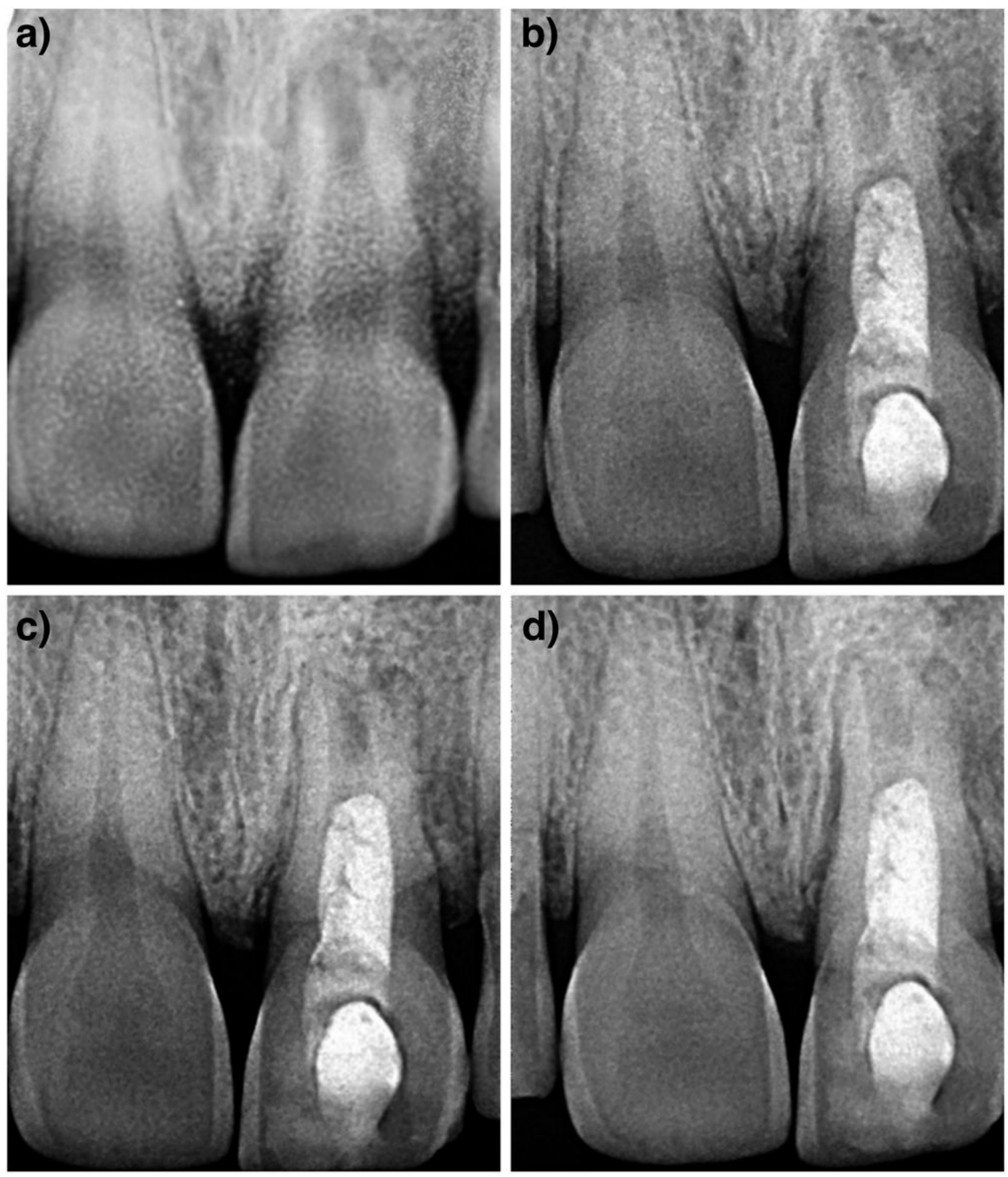

\section{Figure 3}

Case 3: Tooth no. 21- (A)Preoperative radiograph; (B-D)Radiographs at 6 months, 12 months and 24 months follow up period. 